\title{
Height increment of understorey Norway spruces under different tree canopies
}

\author{
Olavi Laiho ${ }^{1}$, Timo Pukkala ${ }^{2^{*}}$ and Erkki Lähde ${ }^{1}$
}

\begin{abstract}
Background: Stands having advance regeneration of spruce are logical places to start continuous cover forestry (CCF) in fertile and mesic boreal forests. However, the development of advance regeneration is poorly known.

Methods: This study used regression analysis to model the height increment of spruce understorey as a function of seedling height, site characteristics and canopy structure.

Results: An admixture of pine and birch in the main canopy improves the height increment of understorey. When the stand basal area is $20 \mathrm{~m} 2 \mathrm{ha}-1$ height increment is twice as fast under pine and birch canopies, as compared to spruce. Height increment of understorey spruce increases with increasing seedling height. Between-stand and within-stand residual variation in the height increment of understorey spruces is high. The increment of 1/6 fastestgrowing seedlings is at least $50 \%$ greater than the average.

Conclusions: The results of this study help forest managers to regulate the density and species composition of the stand, so as to obtain a sufficient height development of the understorey. In pure and almost pure spruce stands, the stand basal area should be low for a good height increment of the understorey.
\end{abstract}

Keywords: Advance regeneration; Continuous cover forestry; Growth model; Picea abies; Uneven-aged management

\section{Background}

Continuous cover forestry (CCF) and other near-natural forest management systems are gaining popularity in several countries (Brunner et al., 2006; Hasenauer, 2006; Schütz et al., 2012). In Finland, public opinion is against clear-felling, and also forest landowners are often unwilling to clear-cut their forests (Valkeapää et al., 2009). According to a recent survey, majority of forest landowners are interested in continuous cover forest management (Kumela and Hänninen, 2011).

Change in general attitude, encouraging results regarding the profitability of uneven-aged forest management (Tahvonen, 2009; Tahvonen et al., 2010; Pukkala et al., 2010, 2011a) and the decreasing importance of pulp and paper industries in Finland's economy have led to increasing criticism against the prevailing silvicultural practices. As a consequence, forestry legislation is being modified (Anonym, 2012), now allowing forest

\footnotetext{
* Correspondence: timo.pukkala@uef.fi

${ }^{2}$ Faculty of Science and Forestry, University of Eastern Finland, P.O. 11180101 Joensuu, Finland

Full list of author information is available at the end of the article
}

landowners to use CCF without any specific justification. Also, instructions for good forestry practice (Anonym, 2006) are being updated. As a result, forest landowners now have the freedom to pursue CCF if they decide so.

The sustainability of CCF depends on the amount and composition of regeneration and the survival and revival of the understorey trees. The first Finnish national forest inventory, conducted in 1921-1924, reported that on the basis of subjective assessments, only $3 \%$ of the forest area had a good-quality understorey (Ilvessalo, 1956). However, a closer look at the inventory results reveals that understoreys have been utilized in forest management much more than one would deduct from their reported occurrence. For example, 10-year old sapling stands covered $7 \%$ of forest land in 1921-1924, but 40 years later the percentage of 50year old stands was $28 \%$ (Mikola, 1966), instead of $7 \%$, suggesting that a majority of 50-year-old stands originated from a released understorey. Therefore, understoreys are more common than indicated by the inventory reports but, due to their spatial heterogeneity and size variation, they are seldomly evaluated as good enough starting points for

\section{空}


even-aged stands. However, practical experience shows that almost all released understoreys develop into fully-stocked productive stands. Sarvas (1951) and Vuokila (1956) found that, in the 1950s, most spruce stands in Finland in fact originated from an understorey.

Looking at the diameter distributions of the sample plots of national forest inventories instead of subjective classifications, shows that there is plenty of advance regeneration in Finnish forests. For example, Lähde et al. (1999) calculated that in mature forests growing on mineral soil sites the total number of understorey Scots pine, Norway spruce and birches (from $50 \mathrm{~cm}$ height to $6 \mathrm{~cm}$ $\mathrm{dbh}$ ) averaged 3000 trees/ha in the 1950s (see also Sarvas, 1944; Laiho et al., 2011)]. Plentiful regeneration was measured also later in both Finland (Lähde, 1992a,b; Lähde et al., 1999) and Sweden (Lundqvist, 1993; Lundqvist and Fridman, 1996; Lundqvist and Nilson, 2007). Pukkala et al. (2011b) calculated that only $5 \%$ of mature Finnish stands had less than 500 understorey trees of pine, spruce and birch per hectare, and $60 \%$ of stands had at least 2000 understorey trees at the end of the 1900s. When seedlings shorter than $1.3 \mathrm{~m}$ were excluded, almost $50 \%$ of stands still had at least 1000 undestorey trees per hectare.

Due to its ecological characteristics, Norway spruce does not thrive in open areas but regenerates easily and grows well under shade-intolerant pioneer species (Kalela, 1949). According to Valkonen (2000), a released spruce understorey may grow almost equally well as a spruce plantation, but the released understorey is more heterogeneous than the plantation would be. In a two-storied birch-spruce stand the volume growth of overstorey birches is often higher than the growth reduction of understorey spruces (Mielikäinen and Valkonen, 1995), making the two-storied stand more productive than either of the one-storied stands alone (see also Isomäki, 1979; Bergqvist, 1999).

According to official silvicultural instructions (Anonym, 2006) good-quality spruce understoreys can be used if they cover large enough continuous areas (at least 300-400 $\mathrm{m}^{2}$ ), are dense and even-sized, and have at least 10-cm long annual shoots. Otherwise, the understorey should be removed, after which the stand should be clear-felled, and a new stand be established by planting. Those criteria, especially the 10-cm rule, are not supported by research, which shows that even a slow-growing stagnant understorey may start growing well (Vuokila, 1982; Ferlin, 2002). Old and large understorey trees revive slowly (Vaartaja, 1951) but may eventually grow as well as young seedlings and saplings (Näslund, 1944; Sarvas, 1951; Vuokila, 1970). According to Kneeshaw et al. (2002), height growth does not respond immediately to increased growth space, but growth reaction occurs first in roots. Typically, it takes 4-5 years for the Norway spruce to fully adapt to the new conditions (Metslaid et al., 2005). The requirement for homogeneity is not relevant in CCF management where uneven size, growth rate and gradual revival of the understorey are benefits rather than shortcomings (Lähde et al., 2010).

High risk of harvesting damages complicates the management of two-storied stands. According to Metsäteho (Kärnä, 2006), a spruce understorey of 6000 seedlings/ha decreases the productivity of harvesting by $5 \%$. Niemistö et al. (2012) found that retaining the understorey spruces decreased the productivity of cutting by $6-17 \%$ as compared with clear cutting where the understorey was not considered. Damage to saplings may be as high as 50\% (Surakka et al., 2011). Saplings near strip roads are vulnerable to additional injuries caused by hauling and forwarding. However, the high number of spruce stands that originate from advance regeneration demonstrates that the harvesting problems are manageable. A slightly more costly harvesting, as compared to clear-felling, is compensated for by savings in stand establishment costs, immediate stocking, soil protection, aesthetic values and benefits to fauna and flora, amongst other things (Ruel et al., 2000).

There are some Finnish studies on the revival and height increment of released Norway spruce understoreys (Koistinen and Valkonen, 1993; Valkonen, 2000) and on the growth of Norway spruce under birch (Mielikäinen and Valkonen, 1995) and spruce (Lin et al., 2012) canopies. Although much research has been done in other countries (see Metslaid et al., 2007 for review), quantitative knowledge about the effects of various factors on the growth of understorey Norway spruce, when they are not released, is very limited. More information and better predictive tools would make it possible to evaluate spruce understoreys from the perspective of CCF management, not only as the starting point of a new even-aged stand.

The aim of this study was to quantify the growth rate of Norway spruce (Picea abies) understorey under different canopies. In the case of abundant understorey the growth rate of the best individuals is relevant for future stand development and for CCF management. Therefore, growth variation among understorey spruces was also analyzed. A regression model was developed for describing the influence of site, canopy structure, and seedling height on the height increment of understorey spruces. The developed model was then used to illustrate the influence of various factors on the height increment of understorey.

\section{Methods}

Altogether 262 temporary plots were measured in different stands on mineral soils in South Finland. Stands having advance regeneration of spruce were selected following a predefined target distribution of different stand types. A matrix of seven species compositions (pine, spruce, birch, pinespruce, pine-birch, spruce-birch, pine-spruce-birch) and stand densities $\left(<10 \mathrm{~m}^{2} \mathrm{ha}^{-1}, 10-30 \mathrm{~m}^{2} \mathrm{ha}^{-1},>30 \mathrm{~m}^{2} \mathrm{ha}^{-1}\right)$ 
was created. Then, 1-3 stands were measured for each class of stand composition and density, separately in two site class categories (herb-rich or better; mesic or poorer) and three different localities. The first 1-3 encountered stands per matrix cell having advance regeneration of spruce were measured in each locality and site category. A selected stand was entered, after which a random direction was chosen and 20 steps were taken to that direction, leading to plot center.

Forest site type and the degree paludification were assessed in the field. For easier modeling, forest site type was converted into site index (dominant height at 100 years) as follows (Vuokila and Väliaho, 1980): OMaT (mesotrophic herb-rich) $30 \mathrm{~m}$; OMT (herb-rich) $27 \mathrm{~m}$; MT (mesic) $24 \mathrm{~m}$; VT (sub-xeric) $21 \mathrm{~m}$; CT (xeric) $18 \mathrm{~m}$. Intermediate values (e.g. $\mathrm{MT}^{+}$and $\mathrm{MT}^{-}$, i.e., fertile and poor mesic) were given intermediate numerical values $(25 \mathrm{~m}$ and $23 \mathrm{~m}$ ). Afterwards, latitude of the site was obtained from a geographical map, and altitude of the stand was obtained from an elevation map. The basal area of canopy trees was measured separately for each species using relascope. The minimum, mean and maximum diameters of each species present in the canopy were measured from the relascope plot. Three trees per species were measured for diameter: the smallest, the largest, and the basal area median tree. The basal area median tree was selected visually, following the practices of Finnish compartment inventory.

At least 20 and at most 30 conifer seedlings and saplings (from $10 \mathrm{~cm}$ height to $4.5 \mathrm{~cm} \mathrm{dbh}$ ) closest to the plot center were measured for $\mathrm{dbh}$, height, and height increment of the previous growing season. This resulted in 5811 spruce seedlings and 197 pines (pine seedlings are not analyzed in this study). When plots that had no overstorey trees were also removed from the data, 5601 observations remained for modeling (Table 1). About $50 \%$ of observations represented mesic growing sites, $38 \%$ represented herb-rich and better sites (OMaT and OMT), and $12 \%$ represented sub-xeric and xeric sites. Trees having dbh greater than $4.5 \mathrm{~cm}$ were defined as canopy trees and the remaining seedlings and saplings were defined as understorey trees.

A mixed-effects model was fitted to the data using SPSS software. Different transformations and combinations of predictors were carefully analyzed to find a model that describes the influence of site, canopy structure and seedling height on the height increment of understorey spruces. The mixed-effect model included a random plot factor, allowing us to divide the residual variation into between-plot and within-plot components.

\section{Results \\ Model}

The model for the height increment of understorey spruces was as follows:

$$
\begin{aligned}
\ln \left(i h_{i j}\right)= & \mathrm{b}_{0}+\mathrm{b}_{1} \sqrt{ } h_{i j}+\mathrm{b}_{2} S I_{j}+\mathrm{b}_{3} P_{j}+\mathrm{b}_{4} G_{j}+\mathrm{b}_{5} G_{\mathrm{S} j} \\
& +\mathrm{b}_{6} \sqrt{ } D_{j}+u_{j}+e_{i j}
\end{aligned}
$$

where $i h_{i j}$ the annual height increment of spruce seedling $i$ in plot $j(\mathrm{~cm}), h$ is height of the seedling $(\mathrm{cm}), S I$ is site index $(\mathrm{m}), P$ is paludification (percent coverage of peat land species among ground vegetation), $G$ is basal area of canopy trees $\left(\mathrm{m}^{2} \mathrm{ha}^{-1}\right), G_{\mathrm{S}}$ is basal area of canopy spruces $\left(\mathrm{m}^{2} \mathrm{ha}^{-1}\right), D$ is mean diameter of canopy trees $(\mathrm{cm}), u_{j} \sim \mathrm{N}\left(0, \sigma_{u}^{2}\right)$ is random plot factor and $e_{i j} \sim \mathrm{N}\left(0, \sigma_{e}^{2}\right)$ is residual.

The degree of explained variance (R2) and the square root of the mean of squared errors (RMSE) were calculated from back-transformed non-logarithmic growth predictions (Table 2). The Baskerville (1972) correction was used in prediction. The correction was $s^{2}\left(e_{i j}\right) / 2+s^{2}$ $\left(u_{j}\right) / 2$ for the fixed part of the mixed-effect model, and $s^{2}\left(e_{i j}\right) / 2$ for the full model. The residuals of the models were visually analyzed and they were found to be normally distributed with a constant variance across the ranges of predictors.

\section{Effect of seedling height and canopy structure}

Height increment of understorey spruces increased as a function of seedling height (Figure 1). When the basal area of canopy trees was $20 \mathrm{~m}^{2} \mathrm{ha}^{-1}$, a four-meter high seedling grew, on average, $50 \mathrm{~cm}$ per year under birch and pine canopies but a one-meter-high seedling grew only $10 \mathrm{~cm} /$ year.

The influence of overstorey tree species was very strong (Figure 1). In a sparse pine or birch stand (basal area 15 $\mathrm{m}^{2} \mathrm{ha}^{-1}$ ) growing on mesic site, the average height increment of a 2-m-high spruce seedlings was $19 \mathrm{~cm} /$ year

Table 1 Description of modeling data (5601 spruce seedlings)

\begin{tabular}{lrrrr}
\hline Variable & Minimum & Maximum & Mean & $\begin{array}{r}\text { Standard } \\
\text { deviation }\end{array}$ \\
\hline Site index, m & 18 & 30 & 24.84 & 2.47 \\
Paludification,\% & 0 & 100 & 7.15 & 19.10 \\
Canopy trees: & 2 & 52 & 19.38 & 10.10 \\
Basal area, m²/ha & 0 & 43 & 4.24 & 8.35 \\
•pine & 0 & 41 & 10.46 & 9.93 \\
• spruce & 0 & 34 & 4.68 & 7.32 \\
•hardwood & 4.2 & 78 & 23.41 & 10.62 \\
Mean diameter, cm & & & & \\
Harwood seedlings: & 0 & 22043 & 2765.92 & 3420.73 \\
Number & 0 & 7 & 2.17 & 1.51 \\
Mean height, m & & & & \\
Spruce seedlings: & 0.1 & 6.0 & 1.51 & 1.12 \\
Height, m & 0.0 & 1.0 & 0.12 & 0.13 \\
Height increment, m & & & & \\
\hline & & & & \\
\hline
\end{tabular}


Table 2 Model parameters. R2 and RMSE have been calculated for the back-transformed non-logarithmic height increment

\begin{tabular}{llr}
\hline Predictor & Coefficient & Estimate \\
\hline Constant & $b_{0}$ & -0.437 \\
$\sqrt{ } h$ & $b_{1}$ & 0.162 \\
$S I$ & $b_{2}$ & 0.0138 \\
$P$ & $b_{3}$ & -0.00653 \\
$G$ & $b_{4}$ & -0.0108 \\
$G_{s}$ & $b_{5}$ & -0.0335 \\
$\sqrt{D}$ & $b_{6}$ & 0.157 \\
& $s\left(u_{j}\right)$ & 0.466 \\
& $s\left(e_{i j}\right)$ & 0.533 \\
& R2 Fixed & $0.510^{1)}$ \\
& R2 Full & $0.773^{(2)}$ \\
& $N$ & 5601 \\
& RMSE Fixed & $9.45^{(1)}$ \\
& RMSE Full & $6.43^{(2)}$ \\
\hline
\end{tabular}

${ }^{(1)}$ Calculated for the fixed part of the mixed-effects model.

${ }^{(2)}$ Calculated for the full mixed-effects model, including the random plot factor.

whereas the predicted increment was only $11 \mathrm{~cm} /$ year in a spruce stand. With a stand basal area of $30 \mathrm{~m}^{2} \mathrm{ha}^{-1}$ the average growth would be $16 \mathrm{~cm} /$ year under pine and birch canopies but only $6 \mathrm{~cm} /$ year under a spruce canopy.

Mean diameter of canopy trees was also a significant predictor of height increment. With a given basal area, seedling increment improved with increasing diameter of the canopy trees (Figure 1). The result implies that seedlings grow better under a small number of large trees than under a larger number of smaller trees.

\section{Effect of site}

Improving site index (fertility) increased the height increment of understorey spruces but the influence was not strong (Figure 2). Height increment was only $8 \%$ better on a herb-rich site (OMT) than on a sub-xeric site (VT). Paludification also affected height increment, the predicted increment being $96 \%$ higher in case of no paludification as compared to a site where the coverage of peat land species in the ground vegetation was $100 \%$. Latitude and elevation were not significant predictors, most probably due to their small range of variation in the modeling data $(330 \mathrm{~km}$ in $\mathrm{y}$ coordinate; $167 \mathrm{~m}$ in elevation).

\section{Growth variation within spruce understorey}

Within- and between-stand variation in the height increment of understorey spruces was visualized by adding \pm $s(u)$ or $\pm s(e)$, i.e. standard deviation of random plot factor $\left(u_{j}\right)$ or standard deviation of residual $\left(e_{i j}\right)$, to the non-logarithmic prediction of the mixed-effect model. Predictions with $u_{j}=s(u)$ are referred to as 'good stand',

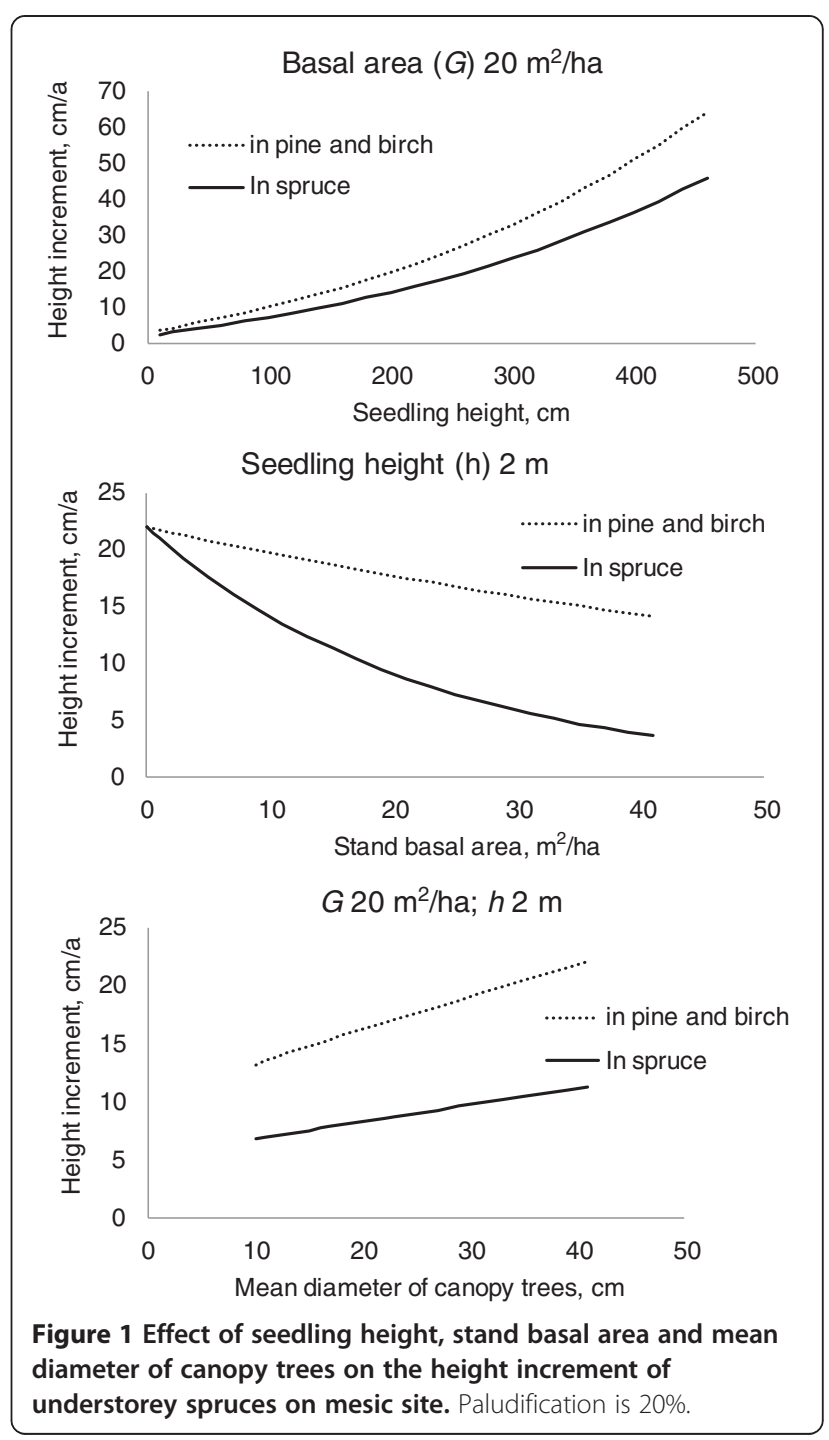

$u_{j}=-s(u)$ as 'bad stand', $e_{i j}=s(e)$ as 'good seedling', and $e_{i j}=-s(e)$ as 'bad seedling'. About 1/6 of stands have the plot factor higher than $s(u)$, and another $1 / 6$ of stands have $u_{j}$ is less than $-s(u)$. Similarly, within a stand, the residual is between $-s(e)$ and $s(e)$ for about $2 / 3$ of seedlings.

The visualizations (Figure 3) show that the variation unexplained by the fixed model predictors is very large, both among stands and among seedlings within a stand. A 'good seedling' grows twice as fast as a "bad seedling", and the average growth of understorey spruces is twice as much in a "good stand" as compared to a "bad stand" when the site index, paludification, amount of hardwood understorey and canopy structure are the same.

\section{Discussion and conclusions}

The study analyzed the dependence of the height increment of understorey spruces on seedling height, site properties and characteristics of the main tree canopy. A 


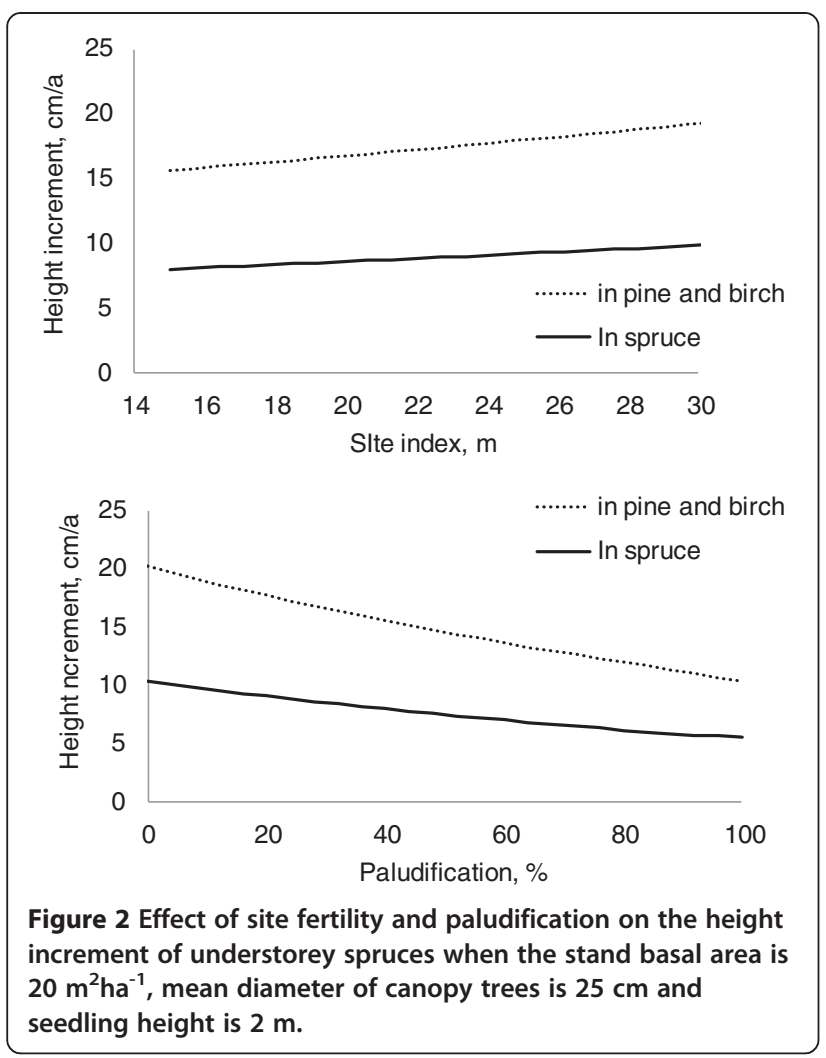

regression model was fitted that describes these relationships. This model should not be used to predict future understorey development because the used dataset is insufficient for genuine growth modeling. Height increment was measured in one year only, which may bring bias to the prediction due to the weather-induced annual growth variation. In addition, selection of the plots had subjective elements and measurement of the stand characteristics was not accurate enough for growth modeling purposes.

Results from this study indicate that 1-2 $\mathrm{m}$ tall spruces typically grow $15-20 \mathrm{~cm} /$ year under birch and pine canopies but only 5-10 cm under spruce canopies. The growth of understory trees improves when they get taller (Lieffers et al., 1996). Taking into account that spruces planted in open areas often need about ten years to reach breast height, the increment of understorey spruces is reasonably good. Given that height increment increases with increasing tree height the future increment would be slightly higher (usually $3-4 \%$ ) than the past increment predicted by the model.

The height increment of the best-growing spruces under sparse pine and birch canopies is not slower than it would be in open area (Valkonen, 2000). This conclusion agrees with the result of Lieffers and Stadt (1994) who found that white spruces (Picea glauca) grow equally well under a canopy of trembling aspen (Populus tremula) as in full light if the light transmittance of the canopy is $40 \%$ or

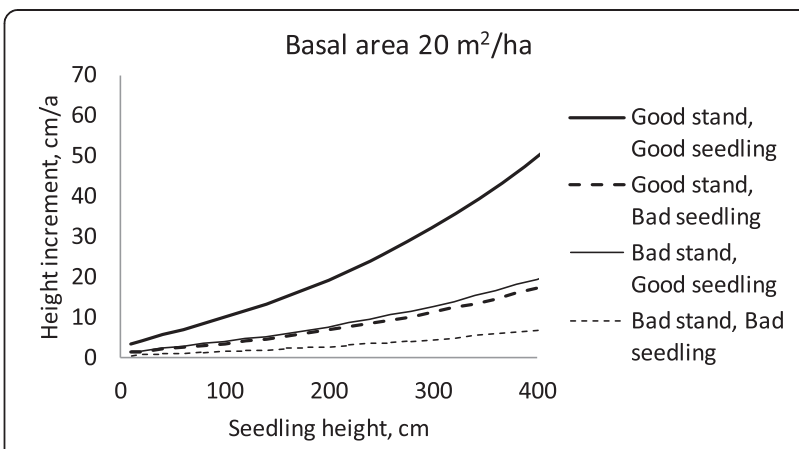

Seedling height $2 \mathrm{~m}$

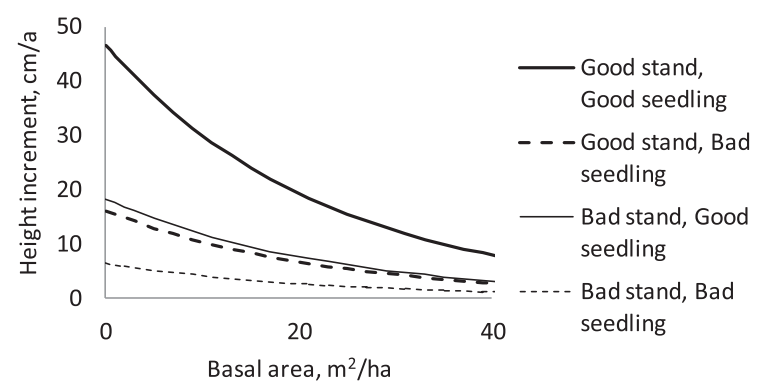

Figure 3 Variation in the height increment of understorey spruces among stands and individuals on mesic site when $50 \%$ of canopy basal area is spruce. Good stand, $u_{j}=s(u) ;$ Bad stand, $u_{j}$ $=-s(u)$; Good seedling, $e_{i j}=s(e)$; Bad seedling, $e_{i j}=-s(e) ; s(u)$ is standard deviation of random plot factor $\left(u_{j}\right) ; s(e)$ is standard deviation of residual $\left(e_{i j}\right)$.

more. Comeau et al. (2003) found that the height increment of subalpine fir (Abies lasiocarpa) and white spruce was only weakly correlated with the light level under paper birch (Betula papyrifera) overstorey.

The results of this study showed that understorey spruces grow much faster under pine and birch canopies than under spruce canopies. Increasing percentage of spruce in the main canopy decreases the growth rate of understorey. Clear beneficial effects of birch and pine admixtures on the growth of larger spruces were recently reported (Pukkala et al. 2013). Earlier, positive mixture effects have been reported by several authors (Mielikäinen 1985; Pukkala et al. 1994; Liang et al. 2005 and Pretzsch et al. 2010). The practical conclusion that can be drawn from this study is that the density of birch and pine stands is not critically important for understorey development but spruce stands must be sparse for fast understory height increment.

It is commonly believed that birch is the best canopy for spruce understorey and birch is the best admixture in a spruce stand. However, the current study showed that this is not necessarily the case; if the effects of stand basal area and site fertility are removed, the growth is equally good or even better (Pukkala et al., 2013) under pine than under birch. The common belief of the smaller 
competitive effect of birch may be partly due to lower stand basal areas and better site fertility of birch stands, as compared to pine stands. Due to fertile site and low stand basal area, understorey spruces often grow well under birch canopies although the competitive effect of pine would be fairly similar with the same basal area.

Increasing size of canopy trees improved the height increment of understorey spruces when stand basal area was constant. The result suggests that open space below the crowns of canopy trees may improve the height increment of spruce understorey. When the vertical distance between the main canopy and understorey is large, the shading effect of canopy trees is more uniformly distributed than in stands where the crown bases are near ground (Kuuluvainen and Pukkala, 1991). Therefore, the beneficial effect of large tree size in the main canopy may be related to more uniform light conditions for understorey spruces.

A result relevant for CCF management was the improving height increment with increasing seedling height (Lieffers et al., 1996). This means that height differences among understorey spruces tend to increase when the understorey develops. The understorey becomes uneven-sized even when it is even-aged. Also the high within-stand variation in height increment and the positive temporal autocorrelation of annual growths of consecutive years (Miina, 1993; Pasanen, 1998; Metslaid et al., 2005) contribute to the differentiation of tree size.

According to Lin et al. (2012) the height increment of the best 100 understory spruces per hectare decreases from 50 to $5 \mathrm{~cm} /$ year when the stand volume of a spruce-dominated stand increases from 50 to $400 \mathrm{~m}^{3} / \mathrm{ha}$. The result agrees well with the predictions of our model. When the height of spruce seedling is $1-3 \mathrm{~m}$ and the basal area of overstorey birches is less than $20 \mathrm{~m}^{2} / \mathrm{ha}$, our model gives fairly similar predictions as an earlier model (Mielikäinen and Valkonen 1995) for two-storied spruce-birch stands. Increasing overstorey basal area decreases height increment more in Mielikäinen and Valkonen (1995) than predicted by the model of this study. It is noteworthy that, similarly to this study, the model of (Mielikäinen and Valkonen 1995) also predicts that increasing tree size in overstorey improves the height increment of spruce understorey if stand basal area remains unchanged. The relationships found in this study are similar to the ones reported earlier for other spruce species (e.g., Filipescu and Comeau 2007). Bergqvist (1999) found that diameter increment of understorey Norway spruces is reduced more than height increment by the competition caused by birch overstorey.

In CCF stands where spruce understorey is abundant, its average growth rate is less relevant than the growth rate of the best individuals (e.g., the best 10 or 30\%, depending on the density of understorey). According to this study, the growth of the best $1 / 6$ of seedlings is at least $50 \%$ better than the average. In sustainable CCF management, only the removed trees need to be replaced by well-growing understorey trees. If the high thinning removes 333 trees/ha, and the density of understorey is 2000 trees/ha, only $1 / 6$ best growing understorey trees are required to take the place of the removed trees. These understorey trees grow at least $50 \%$ faster than a population-averaged model prediction.

Between-stand variation in height increment was also high. This implies, for example, that bad experiences (slow growth) in one forest do not mean that the growth of spruce understorey is always slow. In the best stands, the growth is at least $50 \%$ faster than in an average stand and $100 \%$ faster than among the poorest stands. Therefore, overall recommendations about the utilization of spruce understorey in CCF management cannot be given only on the basis of site characteristics and overstorey stand structure. Instead, the manager needs to assess the vitality of the understorey in the field and adapt the management to the specific conditions of each stand.

Other practical conclusions of the study, from the viewpoint of CCF management, can be summarized as follows. Species composition of the canopy is critically important for the height development of spruce understorey. An admixture of birch and pine should be maintained in the stand as long as possible. If the canopy is a pure spruce stand, it should be thinned to a low basal area for fast understorey development. Between- and within-stand variation in understorey height development is high, which should be taken into account in growth and yield prediction. Using population-averaged model prediction in simulations may lead to biased results and conclusions.

\section{Competing interests}

The authors declare that they have no competing interests.

\section{Authors' contributions}

$\mathrm{OL}$ and EL collected the data. TP fitted the regression model. All authors participated in writing. All authors read and approved the final manuscript.

\section{Author details}

1Joen Forest Program Consulting, Rauhankatu 41, 80100 Joensuu, Finland. ${ }^{2}$ Faculty of Science and Forestry, University of Eastern Finland, P.O. 11180101 Joensuu, Finland.

Received: 30 May 2013 Accepted: 13 August 2013

Published: 26 February 2014

\section{References}

Anonym (2006) Hyvän metsänhoidon suositukset. Metsätalouden kehittämiskeskus Tapio. Metsäkustannus OY, Helsinki, p 100

Anonym (2012) Metsänkäsittelymenetelmien monipuolistaminen jatkotyöryhmän muistio. Ministry of agriculture and forestry. Memorandum 2012(7):53

Baskerville GL (1972) Use of logarithmic regression in the estimation of plant biomass. Can J For Res 2(1):49-53 
Bergqvist G (1999) Wood volume yield and stand structure in Norway spruce understorey depending on birch shelterwood density. For Ecol Manage 122 (3):22-229

Brunner A, Hahn K, Biber P, Skovsgaard JP (2006) Conversion of Norway spruce: A case study in Denmark based on silvicultural scenario modeling. In: Hasenauer H (ed) Sustainable Forest Management. @Springer, Berlin, Heidelberg, pp 343-372

Comeau PG, Wang JR, Letchford T (2003) Influences of paper birch competition on growth of understory white spruce and subalpine fir following spacing. Can J For Res 33(10):1962-1973

Ferlin F (2002) The growth potential of understorey silver fir and Norway spruce for uneven-aged forest management in Slovenia. Forestry 75(4):375-383

Filipescu CN, Comeau PG (2007) Aspen competition affects light and white spruce growth across several sites in western Canada. Can J For Res 37:17011713

Hasenauer H (2006) Concepts within tree growth modeling. In: Hasenauer H (ed) Sustainable Forest Management. CSpringer, pp 3-17

Ilvessalo Y (1956) Suomen metsät vuosista 1921-1924 vuosiin 1951-1953. Kolmeen valtakunnan metsien inventointiin perustuva tutkimus. Enslish Summary: The forests of Finland from 1921-1924 to 1951-1953. The survey based on three national forest inventories. Comm Inst For Fenn 47(1):1-227

Isomäki A (1979) Kuusialikasvoksen vaikutus männikön kasvuun, tuotokseen ja tuottoon. Summary: The effect of spruce undergrowth on the increment, yield and returns of a pine stand. Folia For 392:13

Kalela EK (1949) Ecological character of tree species and its relation to silviculture. Acta For Fenn 57(1):1-35

Kärnä K (2006) Alikasvoksen vaikutukset ensiharvennuspuun korjuuseen. Summary: impact of undergrowth on the harvesting of first-thinning stands. Metsätehon katsaus 18:4

Kneeshaw DD, Williams H, Nikinmaa E, Messier C (2002) Patterns of above- and below-ground response of understory conifer release 6 years after partial cutting. Can J For Res 32:255-265

Koistinen E, Valkonen S (1993) Models for height development of Norway spruce and Scots pine advance growth after release in Southern Finland. Silva Fenn 27(3):179-194

Kumela H, Hänninen H (2011) Metsänomistajien näkemykset metsänkäsittelymenetelmien monipuolistamisesta. Working Papers of the Finnish Forest Research Institute 203:76

Kuuluvainen T, Pukkala T (1991) Interaction between canopy architecture and photosynthetically active radiation at different latitudes: simulation experiments and their ecological implications. Naturalia Monspeliensia Special Issue (L'arbre. Biologie et developpement):277-291

Lähde E (1992a) Regeneration potential of all-sized spruce-dominated stands. In: Hagner M (ed) Silvicultural Alternatives. Proceedings from an Internordic Workshop, June 22-25 1992. The Swedish University of Agricultural Sciences, Department of Silviculture, Reports 35, Umeå, pp 111-116

Lähde E (1992b) Natural regeneration of all-sized spruce-dominated stands treated by single tree selection. In: Hagner M (ed) Silvicultural Alternatives. Proceedings from an Internordic Workshop, June 22-25 1992. The Swedish University of Agricultural Sciences, Department of Silviculture, Reports 35, Umeå, pp 117-123

Lähde E, Laiho O, Lin J (2010) Silvicultural alternatives in an uneven-sized forest dominated by Picea abies. J For Res 15:14-20

Lähde E, Laiho O, Norokorpi Y, Saksa T (1999) Uudistuminen ja kasvatus. In: Luontaisesti syntyneiden sekametsien kehitys ja metsänhoito. The Finnish Forest Research Institute, Research Notes 719, Helsinki, pp 32-58

Laiho O, Lähde E, Pukkala T (2011) Uneven- vs. even-aged management in Finnish boreal forests. Forestry 84(5):547-556

Liang J, Buongiorno J, Monserud RS (2005) Growth and yield of all-aged Douglas-fir/western hemlock forest stands: a matrix model with stand diversity effects. Can J For Res 35:2369-2382

Lieffers W, Stadt KJ (1994) Growth of understory Picea glauca, Calamagrostis canadensis, and Epilobium angustifolium in relation to overstory light transmission. Can J For Res 24(6):1193-1198

Lieffers VJ, Stadt KJ, Navratil S (1996) Age structure and growth of understory white spruce under aspen. Can J For Res 26(6):1002-1007

Lin CJ, Laiho O, Lähde E (2012) Norway spruce (Picea abies L.) regeneration and growth of understory trees under single-tree selection silviculture in Finland. Eur J For Res 131:683-691

Lundqvist $L$ (1993) Changes in the stand structure on permanent Picea abies plots managed with single-tree selection. Scand J For Res 8:510-517
Lundqvist L, Fridman E (1996) Influence of local stand basal area on density and growth of regeneration in uneven-aged Picea abies stands. Scand J For Res 11:364-369

Lundqvist L, Nilson K (2007) Regeneration dynamics in an uneven-aged virgin Norway spruce forest in northern Sweden. Scand J For Res 22:304-309

Metslaid M, llisson T, Vicente M, Nikinmaa E, Jõgiste K (2005) Growth of advance regeneration of Norway spruce after clear-cutting. Tree Physiol 25:793-801

Metslaid M, Jõgiste K, Nikinmaa E, Moser KW, Porcar-Castell A (2007) Tree variables related to growth response and acclimation of advance regeneration of Norway spruce and other coniferous species after release. For Ecol Manage 250:56-63

Mielikäinen K (1985) Koivusekoituksen vaikutus kuusikon rakenteeseen ja kehitykseen. Summary: Effect of an admixture of birch on the structure and development of Norway spruce stands. Comm Inst For Fenn 133:1-79

Mielikäinen K, Valkonen S (1995) Kaksijaksoisen kuusi-koivu-sekametsikön kasvu. Metsätieteen aikakauskirja 1995(2):81-97

Miina J (1993) Residual variation in diameter growth in a stand of Scots pine and Norway spruce. For Ecol Manage 58:111-128

Mikola P (1966) Alikasvosten merkitys metsien uudistamisessa. Summary: Significance of undergrowth in reforestation. Metsätaloudellinen aikakauslehti 83(1):4-7

Näslund M (1944) Den gamla norrländska granskogens reaktionsförmåga efter genomhuggning. Referat: Die reaktionsfähigkeit des alten norrländischen fichtenwaldes nach durchlauung. Medd Stat Skogsförsöksanstalt 33:1-194

Niemistö P, Korpunen H, Laurén A, Salomäki M, Uusitalo J (2012) Impact and productivity of harvesting while retaining young understorey spruces in final cutting of downy birch. Silva Fenn 46(1):81-97

Pasanen K (1998) Integrating variation in tree growth into forest planning. Silva Fenn 32(1):11-25

Pretzsch H, Block J, Dieler J, Dong PH, Kohnle U, Nagel J, Spellmann H, Zingg A (2010) Comparison between the productivity of pure and mixed stands of Norway spruce and beach. Ann For Sci 67:712p1-712p7, DOI: 10.1051/forest/ 2010037

Pukkala T, Vettenranta J, Kolström T, Miina J (1994) Productivity of a mixed Scots pine - Norway spruce stand. Scand J For Res 9:143-153

Pukkala T, Lähde E, Laiho O (2010) Optimizing the structure and management of uneven-sized stands of Finland. Forestry 83:129-142

Pukkala T, Lähde E, Laiho O, Salo K, Hotanen J-P (2011a) A multifunctional comparison of even-aged and uneven-aged forest management in a boreal region. Can J For Res 41:851-862

Pukkala T, Lähde E, Laiho O (2011b) Metsän jatkuva kasvatus. Joen Forest Program Consulting, Joensuu, 229

Pukkala T, Lähde E, Laiho O (2013) Species interactions in even- and unevenaged boreal forests. J Sust For 32:1-33

Ruel JC, Messier C, Doucet R, Claveau Y, Comeau P (2000) Morphological indicators of growth response of coniferous advance regeneration to overstory removal in the boreal forest. For Chron 76:633-642

Sarvas R (1944) Tukkipuun harsintojen vaikutus Etelä-Suomen yksityismetsiin Referat: Einwirkung der Sägestammplenterungen auf die Privatwälder Südfinnlands. Comm Inst For Fenn 33(1):1-268

Sarvas R (1951) Tutkimuksia puolukkatyypin kuusikoista. Summary: Investigations into the spruce stands of Vaccinium type. Comm Inst For Fenn 39(1):1-82

Schütz J-P, Pukkala T, Donoso PJ, von Gadow K (2012) Historical emergence and current application of CCF. In: Pukkala T, Gadow K (eds) Continuous Cover Forestry. Book Series Managing Forest Ecosystems Vol. 24. @Springer Science + Business Media B.V, Dordrecht, pp 1-28

Surakka H, Sirén M, Heikkinen J, Valkonen S (2011) Damage to saplings in mechanized selection cutting in uneven-aged Norway spruce stands. Scand J For Res 26(3):232-244

Tahvonen O (2009) Optimal choice between even- and uneven-aged forestry. Natural Res Modelling 22:289-321

Tahvonen O, Pukkala T, Laiho O, Lähde E, Niinimäki S (2010) Optimal management of uneven-aged Norway spruce stands. For Ecol Manage 260:106-115

Vaartaja O (1951) Alikasvosasemasta vapautettujen männyntaimistojen toipumisesta ja merkityksestä metsänhoidossa. English Summary: On the recovery of released pine advance growth and its silvicultural importance. Acta For Fenn 59(3):1-133

Valkeapää A, Paloniemi R, Vainio A, Vehkalahti K, Helkama K, Karppinen $\mathrm{H}_{\text {, }}$ Kuuluvainen J, Ojala A, Rantala T, Rekola M (2009) Suomen metsät ja 
metsäpolitiikka - kansalaisten näkemyksiä. University of Helsinki, Department of Forest Economics. Reports 55:36

Valkonen S (2000) Kuusen taimikon kasvattamisen vaihtoehdot Etelä-Suomen kivennäismailla: Puhdas kuusen viljelytaimikko, vapautettu alikasvos ja kuusikoivusekataimikko. The Finnish Forest Research Institute, Research Papers 763:83

Vuokila Y (1956) Etelä-Suomen hoidettujen kuusikoiden kehityksestä. Summary: On the development of managed spruce stands in southern Finland. Comm Inst For Fenn 48(1):1-138

Vuokila Y (1970) Harsintaperiaate kasvatushakkuissa. Summary: Selection from above in intermediate cuttings. Acta For Fenn 110:1-45

Vuokila Y (1982) Antakaa luonnon auttaa. Metsä ja Puu 99(12):6-8

Vuokila Y, Väliaho H (1980) Viljeltyjen havumetsiköiden kasvumallit. Summary: Growth and yield models for conifer cultures in Finland. Comm Inst For Fenn 99(2):271

doi:10.1186/2197-5620-1-4

Cite this article as: Laiho et al:: Height increment of understorey Norway spruces under different tree canopies. Forest Ecosystems 2014 1:4.

Submit your manuscript to a SpringerOpen ${ }^{\circ}$ journal and benefit from:

- Convenient online submission

- Rigorous peer review

- Immediate publication on acceptance

- Open access: articles freely available online

- High visibility within the field

- Retaining the copyright to your article

Submit your next manuscript at $\boldsymbol{\nabla}$ springeropen.com 